\title{
Determinants of Life Satisfaction among the Clergy in Indian Orthodox Church: A Study in Central Travancore, Kerala State
}

\author{
Georgy Joseph ${ }^{1}$, Dr. N. Rajeev Kumar ${ }^{2}$
}

\section{ABSTRACT}

The aim of the study is to determine the factors of Life Satisfaction among the Clergy from Indian Orthodox Church in central Travancore, Kerala state. For this study the researcher takes the 75 samples, 25 each from three diocese namely Thumpamon, Kollam and Kottayam. The study is primarily an empirical research using Quantitative methods. The following objectives were proposed for the study.1. To study the life satisfaction of the clergy of the Indian Orthodox Church. 2. To study the impact of Diocese, Age income, Education, Marital status, Duration in Ministry, Number of families in parish, Employment status of spouse, Living arrangement, Number of children, Occupation of children, on the life satisfaction of the study group. 3. To study the life satisfaction of the married and unmarried clergy of the Indian Orthodox Church. From the analysis we found that the major factors affecting the life satisfaction are age, income and number of families in the parish. Also there is no difference between the Life Satisfaction among married and unmarried Clergy. The secular education and marital status have a diminutive influence over the life satisfaction of the clergy. The study concluded with suggestions to the Church, Asrams and Family of the Clergy.

Keywords: Clergy, Life Satisfaction, Indian Orthodox Church.

Life satisfaction is now a frequently used term that has much theological and psychological relevance. Life satisfaction is the overall feeling of satisfaction and fulfillment regarding expectation. This is integrated with an inner sense of achievement, meaning and a general assurance of well being. Cribb defines it as "An assessment of the overall conditions of existence as derived from a comparison of one's aspirations to ones actual achievements" (Cribb ,Kenny,2008) It is often conceptualized as one of three key aspects of subjective well being (Daniel K Mroczek \& Arvin Spiro III, 2005).

\footnotetext{
${ }^{1}$ Research Scholar, Bharathiar University, Coimbatore

2 Asso. Professor, SBS, M G University, Kottayam

*Responding Author

(C) 2016 I G Joseph, N Kumar; licensee IJIP. This is an Open Access Research distributed under the terms of the Creative Commons Attribution License (http://creativecommons.org/licenses/by/2.0), which permits unrestricted use, distribution, and reproduction in any Medium, provided the original work is properly cited.
} 


\section{Determinants of Life Satisfaction among the Clergy in Indian Orthodox Church: A Study in Central Travancore, Kerala State}

The environmental factors that are believed to affect life satisfaction are varied. Lot of studies have been made with various variables like marital status, living arrangement, levels of education and income, cognitive vitality, changes in life time (Fillit ,HM, et al, 2006), intellectual skills, emotional health age, social activity (Capsi A and Elder GH,).

Life satisfaction is a Latin word that means to make or do enough Satisfaction with one's or the fulfillment of one's wants and needs for one's life as a whole. Because it is inherently an evaluation, judgments of life satisfaction have a large cognitive component (Sousa, L., \& Lyubomirsky, S. 2001, p.667-676). It is one of three major indicators of well-being: life satisfaction, positive effect, and negative affect” (Sousa, L, \& Lyubomirsky, S, 2001, p.680)

\section{REVIEW OF LITERATURE}

As far as the researcher's knowledge is concerned, there has not been any previous research on determinants of Life Satisfaction among the Clergy in Indian Orthodox Church: A study in central Travancore, Kerala state. Some early studies related to this field are; PW .Blanton, and Morris, ML studies about 'Work-related predictors of physical symptom and emotional wellbeing among clergy and spouses'. Wolfradt conduct the analysis about 'Sleep behaviors, life satisfaction and perceived performance stress in school'. T. Yoshimura conducted the study about 'Prospective cohort study of stress, life satisfaction, self-rated health, insomnia, and suicide death 'the locale is in Japan. E .Huovinen conduct psychopathological study about 'Asthma in relation to personality traits, life satisfaction, and stress: a prospective study among 11000 adults'. J A. Makinen conduct the research in 'The differential effects of project stress on life-satisfaction'.Shirley Foster Hartley conducted a field research in among the clergy wife's. The study is' Marital Satisfaction among Clergy Wives' A 138-item questionnaire was completed by 448 wives of clergy in six mainline Protestant denominations, chosen to represent relatively orthodox to liberal theologies.

\section{Definitions and related factors}

Abraham Maslow, in his "Theory of Met motivation" describes satisfaction of the hierarchy of needs as the pre requisite for self actualization. Self actuating individually by definitions already suitably gratified in their basic needs, are now motivated in other higher ways, to be called met motivation. This is to say that they have a feeling of belonging and rootedness, their love needs, they have status and place in life and respect from other people and they have reasonable feeling of worth and self respect (H, Maslow, 1976, p.289).Maslow described peak experiences as transient moments of self actualization (H. Maslow, 1976, p.46) Which as life validating in that they make life worthwhile and heal the splits within and among persons between person and the world. Based on this theory life satisfaction in ministry/spiritual in the result of meeting all the basic needs and reaching a stage of seeing life worthwhile and satisfactory. Seeing one's life as meaningful is necessary of course, to construct a satisfying conclusion (Jim Mc Martin, 1995, p.231) Life satisfaction can be seen as the result of the integration. 


\section{Determinants of Life Satisfaction among the Clergy in Indian Orthodox Church: A Study in Central Travancore, Kerala State}

Alfred Adler's individual psychology focuses on the uniqueness of every individual and believes in the imperfectability of human beings (Adler, p.24).Inferiority complex which motives Superiority and perfection (Antony, John, 2003 , p.71). The way a person works out there feeling of inadequacy, there for superiority results in a life style ( Kemp, Charles F,1985, p.44). The style of life determines how a person adopts to obstacles in his life and ways in which he creates solutions and means of achieving goals (Sharf, Richards, 2004, p.122). He recognizes the influence of physical sociological and psychological conditions in the formation of self (Mosak, Harold H, 1919, p.44-45). He claims that each individual is a social being and those personalities are shared by social environments and interaction and not by our efforts to satisfy our biological needs (Dunae P. ShultZ and Sidnay EllenshuttZ, 2000, p.121) Family Life Satisfaction is understood as the satisfaction derived from the family atmosphere, the mutual interaction with the family members. Family Life Satisfaction is the internal feeling of satisfaction, which is often a good adjustment with family members and family surroundings (Erickson, Eric, 1959, p.45-76).

\section{Special Condition of Orthodox Clergy}

Among Orthodox clergy there are three major stressors are reported: Being under the control and misunderstood by the hierarch, being considered an employee of the Parish Council who has the final say in all administrative matters, for clergy with family the demands of being husband and father.

St. John of Kronstadt demonstrates the nature and responsibility of the Christian priesthood: a worthy priest, who, like the seraphim, would burn before the Lord with love, praise and gratitude for the wonders of His mercy and His wisdom ... As a light and heat are inseparable from the sun, so should holiness, a zeal to teach, and love and compassion for all, be inseparable from the person of the priest. For whose dignity does he bear? Christ's ... God Himself ... By myself I am nothing, but by the grace of the priesthood I become the means of healing. Though me the grace of the Holy Spirit gives new life; the Body and Blood of Christ to the faithful ... uniting them with God (St.John of Kronstadt, 1994).

\section{Statement of the problem}

The study intends to measure the determine the factors of Life Satisfaction among the Clergy in Indian Orthodox Church: A study in central Travancore, Kerala state.

\section{OBJECTIVES}

1. To study the life satisfaction of the clergy in the Indian Orthodox Church

2. To study the impact of Diocese, Age, income, Education, Marital status, Number of families in parish on the life satisfaction of the Study group.

3. To study the life satisfaction of married and unmarried clergy 


\section{Determinants of Life Satisfaction among the Clergy in Indian Orthodox Church: A Study in Central Travancore, Kerala State}

\section{Hypothesis}

1. There will be no effect of the life satisfaction among the Clergy in the Indian Orthodox Church.

2. There will be no significant relationship between of Diocese, Age, income, Education, Marital status, Number of families in parish on the life satisfaction on the life of Satisfaction on the study group.

4. There is no effect of life satisfaction among the married and unmarried clergy.

\section{RESEARCH METHODOLOGY}

The universe of the study consisted of Orthodox Clergy working in three dioceses. The sample for the study was selected from Orthodox Clergy of Kerala state, from three Dioceses namely Kottayam, Kollam and Thumpamon, a group of married Clergy and unmarried clergies. The sample included 75 clergies in the age group between 28 -62 years from three diocese of Kerala state. The tools are distributed and collected from 83 clergies. Randomly selected 75 clergies, 25 from each diocese. The study uses quantitative data analysis method.

\section{Tools and techniques}

The tools for sampling are the following;

i) Schedule for socio-demographic and background information

ii) Life Satisfaction Inventory

In addition to these qualitative questions were added to the inventory to elicit important information from the respondents. Life Satisfaction inventory developed from Adjustment inventory of Ramamurthy (1968) Subramaniam(1989) Family Life Satisfaction Inventory by Jacob Cherian(1999). In addition to this a data sheet was used. The statistical test applied for the present study were t-test, chi-square test, Analysis Of Variance (one-way ANOVA) and Dunkan's test .

Table 1, Distribution of Sample According to Age

Age

\begin{tabular}{|l|r|r|}
\hline & Frequency & Percent \\
\hline Up to 30 Years & 7 & 9.3 \\
30-40 years & 23 & 30.7 \\
40-50 years & 21 & 28.0 \\
50-60 years & 13 & 17.3 \\
Above 60 years & 11 & 14.7 \\
Total & 75 & 100.0 \\
\hline
\end{tabular}


Table 1.0 shows the frequency distribution of age among five groups. Age group 1 is up to 30 years, group 2 is 30 - 40 years, group 3 is $40-50$ years, group 4 is 50-60 years and group 5 is Above 60 years.

Table 2, Distribution of Sample According to Monthly Income

Monthly Income

\begin{tabular}{|l|r|r|}
\hline & & \\
& Frequency & Percent \\
\hline Below Rs 5000 & 26 & 34.7 \\
Rs 5000-10000 & 39 & 52.0 \\
Rs 10000-25000 & 10 & 13.3 \\
Total & 75 & 100.0 \\
\hline
\end{tabular}

Table 2.0 shows the frequency distribution of monthly income among three groups. Group 1 is below 5000 Rs, group 2 is $5000-10000$ Rs, and group 3 is 10000-25000 Rs.

Table 3 Distribution of Sample According to General Education

General Education

\begin{tabular}{|l|r|r|}
\hline & & \\
& Frequency & Percent \\
\hline Under graduates & 6 & 8.0 \\
Graduates & 44 & 58.7 \\
Post Graduates & 25 & 33.3 \\
Total & 75 & 100.0 \\
\hline
\end{tabular}

Table 3.0 shows the frequency distribution of general education among three groups. Group1 is Under Graduate, group 2 is Graduate, and group 3 is Post Graduate. 
Determinants of Life Satisfaction among the Clergy in Indian Orthodox Church: A Study in Central Travancore, Kerala State

Table 4, Distribution of Sample According to Marital Status

Marital Status

\begin{tabular}{|l|r|r|}
\hline & & \\
& Frequency & Percent \\
\hline Married & 52 & 69.3 \\
Unmarried & 23 & 30.7 \\
Total & 75 & 100.0 \\
\hline
\end{tabular}

Table 4.0 shows the frequency distribution of marital status among two groups. Group1 is Married, group 2 is Unmarried.

Table 5, Distribution of Sample According to Duration of Ministry

Duration of Ministry

\begin{tabular}{|l|r|r|}
\hline & Frequency & Percent \\
\hline Up to 5 years & 17 & 22.7 \\
5-10 years & 12 & 16.0 \\
10-20 years & 17 & 22.7 \\
20-35 years & 14 & 18.7 \\
Above 35 years & 15 & 20.0 \\
Total & 75 & 100.0 \\
\hline
\end{tabular}

Table 5.0 shows the frequency distribution of duration of ministry five groups. Group 1 is up to5 years, group 2 is 5-10 years, group 3 is 10-20 years, group 4 is 20-35 years and group 5 is Above 35 years

Table 6, Distribution of Sample According to No of Families in Parish

No of families in Parish

\begin{tabular}{|l|r|r|}
\hline & Frequency & Percent \\
\hline Below 100 & 23 & 30.7 \\
$100-500$ & 39 & 52.0 \\
Above 500 & 13 & 17.3 \\
Total & 75 & 100.0 \\
\hline
\end{tabular}


Table 6.0 shows the frequency distribution of no of families in parish among three groups. Group1 is below 100, group 2 is 100-500, and group 3 is Above 500.

Table 7 Distribution of Sample According to Employment of Spouse

\section{Employment of Spouse}

\begin{tabular}{|l|r|r|}
\hline & & \\
& Frequency & Percent \\
\hline Employed & 28 & 53.8 \\
Unemployed & 24 & 46.2 \\
Total & 52 & 100.0 \\
\hline
\end{tabular}

Table 7 shows the frequency distribution of employment of spouse among two groups. Group1 is employed, group 2 is Unemployed.

Table 8 Distribution of Sample According to Theological Education

Theology Education

\begin{tabular}{|l|r|r|}
\hline & & \\
& Frequency & Percent \\
\hline Under graduates & 26 & 34.7 \\
Graduates & 42 & 56.0 \\
Post Graduates & 7 & 9.3 \\
Total & 75 & 100.0 \\
\hline
\end{tabular}

Table 8.0 shows the frequency distribution of theological education among three groups. Group1 is Under Graduate, group 2 is Graduate, and group 3 is Post Graduate.

Table 9 Distribution of Sample According to Duration of Marital Life

Duration of Marital Life

\begin{tabular}{|l|r|r|}
\hline & & \\
& Frequency & Percent \\
\hline Up to 5 years & 9 & 17.3 \\
5-10 years & 16 & 30.8 \\
10-20 years & 16 & 30.8 \\
20-35 years & 11 & 21.2 \\
Total & 52 & 100.0 \\
\hline
\end{tabular}


Table 9.0 shows the frequency distribution of duration of ministry four groups. Group 1 is up to5 years, group 2 is 5-10 years, group 3 is 10-20 years, and group 4 is 20-35 years

\section{Life Satisfaction and Diocese}

A Testing whether life satisfaction scores differ with dioceses. Statistical tool used is one-way ANOVA.

\section{Descriptives}

Life Satisfaction Score

\begin{tabular}{|l|r|c|r|}
\hline & & & \\
& $\mathrm{N}$ & Mean & Std. Deviation \\
\hline Kollam & 25 & 166.2800 & 18.64028 \\
Kottayam & 26 & 159.1538 & 16.09644 \\
Thumpamon & 24 & 173.0417 & 21.88801 \\
Total & 75 & 165.9733 & 19.53719 \\
\hline
\end{tabular}

ANOVA

Life Satisfaction Score

\begin{tabular}{|l|r|r|r|r|r|}
\hline & $\begin{array}{c}\text { Sum of } \\
\text { Squares }\end{array}$ & df & Mean Square & F & Sig. \\
\hline Between Groups & 2410.564 & 2 & 1205.282 & 3.359 & .040 \\
Within Groups & 25835.383 & 72 & 358.825 & & \\
Total & 28245.947 & 74 & & & \\
\hline
\end{tabular}

Since the value of $F$ statistic is 3.359 which is significant at 0.05 level, we reject the null hypothesis. Thus life satisfaction scores of the clergy differ with dioceses. The life satisfaction scores of clergy in Kottayam and Kollam are not significantly different; also the life satisfaction scores of clergy in Kollam and Thumpamon are not significantly different. However the life satisfaction scores of the clergy in Kottayam and Thumpamon are significantly different. 


\section{Life satisfaction scores and age}

ANOVA

Life Satisfaction Score

\begin{tabular}{|l|r|r|r|r|r|}
\hline & \multicolumn{1}{|c|}{$\begin{array}{c}\text { Sum of } \\
\text { Squares }\end{array}$} & df & Mean Square & F & Sig. \\
\hline Between Groups & 6460.796 & 4 & 1615.199 & 5.190 & .001 \\
Within Groups & 21785.150 & 70 & 311.216 & & \\
Total & 28245.947 & 74 & & & \\
\hline
\end{tabular}

Since the value of $\mathrm{F}$ statistic is 5.19 which is significant at 0.01 level, we reject the null hypothesis. Thus life satisfaction scores of the clergy differ with age.

\section{Life Satisfaction Score}

Duncan $^{a, b}$

\begin{tabular}{|l|r|r|r|r|}
\hline & & \multicolumn{3}{|c|}{ Subset for alpha $=.05$} \\
\cline { 3 - 5 } Age & $\mathrm{N}$ & 1 & \multicolumn{1}{|c|}{3} \\
\hline Above 60 years & 11 & 151.6364 & & \\
$50-60$ years & 13 & 160.6154 & 160.6154 & \\
40-50 years & 21 & & 166.8571 & \\
30-40 years & 23 & & 168.0435 & \\
Up to 30 Years & 7 & & & 189.0000 \\
Sig. & & .208 & .328 & 1.000 \\
\hline
\end{tabular}

Means for groups in homogeneous subsets are displayed.

a. Uses Harmonic Mean Sample Size $=12.444$.

b. The group sizes are unequal. The harmonic mean of the group sizes is used. Type I error levels are not guaranteed.

The life satisfaction scores of the clergy in the age group up to 30 years are significantly higher than that of other age groups and there is significant difference between this group and all other groups.

\section{Life Satisfaction Scores and Income}

\section{Monthly Incomes of clergy}

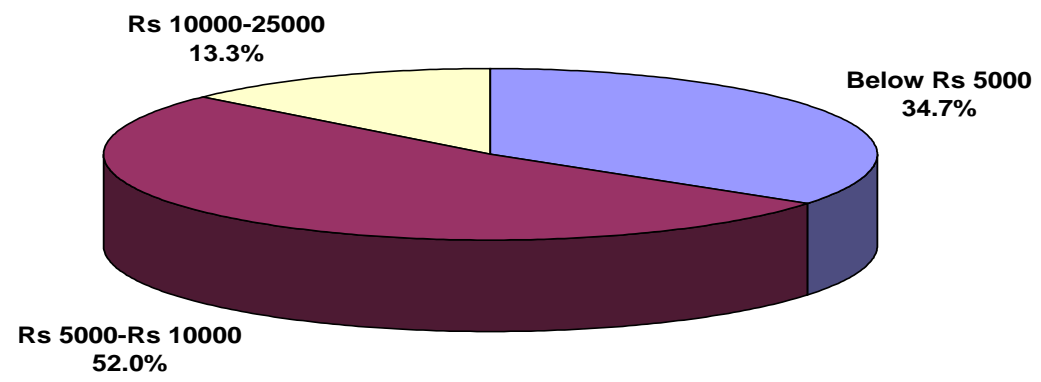

Pie Diagram Shows the percentage level of monthly income of clergy from the sample group. 
Testing whether life satisfaction scores differ with income. Statistical tool used is one-way ANOVA.

Since the value of $\mathrm{F}$ statistic is 4.609 which is significant at 0.05 level, we reject the null hypothesis. Thus life satisfaction scores of the clergy differ with income. The Duncan's test is used to find out which income groups differ significantly when taken pair-wise.

The life satisfaction scores of the group having income below Rs 5000 and the group having income between Rs 5000-10000 are not significantly different, whereas the life satisfaction scores of other groups are significantly different when taken pair-wise.

\section{Life Satisfaction and general Education}

Testing whether life satisfaction scores differ with education. Statistical tool used is the one-way ANOVA.

\section{ANOVA}

Life Satisfaction Score

\begin{tabular}{|l|r|r|r|r|r|}
\hline & $\begin{array}{c}\text { Sum of } \\
\text { Squares }\end{array}$ & $\mathrm{df}$ & Mean Square & $\mathrm{F}$ & Sig. \\
\hline Between Groups & 501.467 & 2 & 250.733 & .651 & .525 \\
Within Groups & 27744.480 & 72 & 385.340 & & \\
Total & 28245.947 & 74 & & & \\
\hline
\end{tabular}

Since the value of $\mathrm{F}$ statistic is 0.651 which is not significant at 0.05 levels, we accept the null hypothesis. Thus life satisfaction scores of the clergy do not differ with general education.

\section{Life Satisfaction Scores and Marital Status}

\section{Marital Status of clergy}

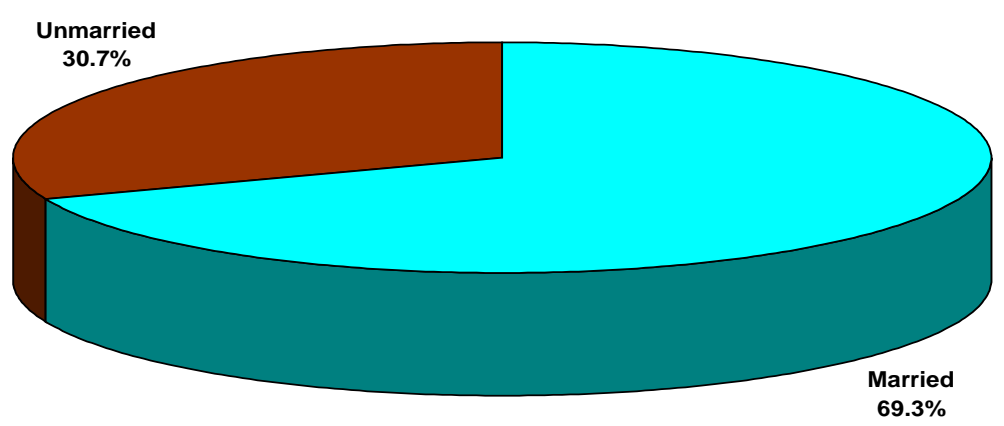

Fig 3 Pie Diagram Shows the percentage level of marital status of the clergy from the sample group. 


\section{Determinants of Life Satisfaction among the Clergy in Indian Orthodox Church: A Study in Central Travancore, Kerala State}

The value of the t statistic is 0.849 which is not significant at 0.05 levels. Hence we accept the null hypothesis. That is there is no significant difference between the life satisfaction scores of clergy who are married and who are unmarried.

\section{Life Satisfaction Scores and Duration of Ministry}

Testing whether life satisfaction scores differ with duration of ministry. Statistical tool used is one-way ANOVA.

Since the value of $\mathrm{F}$ statistic is 7.522 which are significant at 0.01 levels, we reject the null hypothesis. Thus life satisfaction scores of the clergy differ with duration of ministry.

The Duncan's test is used to find out the groups which show significant difference when taken pair-wise.

\section{Life Satisfaction Score}

\begin{tabular}{|c|c|c|c|}
\hline \multirow[b]{2}{*}{ Duration of Ministry } & \multirow[b]{2}{*}{$\mathrm{N}$} & \multicolumn{2}{|c|}{ Subset for alpha $=.05$} \\
\hline & & 1 & 2 \\
\hline 20-35 years & 14 & 154.7143 & \\
\hline Above 35 years & 15 & 155.6667 & \\
\hline $10-20$ years & 17 & 162.2941 & \\
\hline 5-10 years & 12 & & 177.3333 \\
\hline Up to 5 years & 17 & & 180.0000 \\
\hline Sig. & & .253 & .668 \\
\hline
\end{tabular}

a. Uses Harmonic Mean Sample Size $=14.746$.

b. The group sizes are unequal. The harmonic mean of the group sizes is used. Type I error levels are not guaranteed.

The life satisfaction scores of the groups namely up to 5 years and 5-10 years are not significantly different, also the life satisfaction scores of the groups namely 10-20 years, 20-35 years and above 35 years are also not significantly different. However the life satisfaction scores of other groups are significantly different when taken pair-wise.

\section{Life Satisfaction Scores and No. of families in the parish}

Testing whether life satisfaction scores differ with no of families in the parish. Statistical tool used is one-way ANOVA.

Since the value of $\mathrm{F}$ statistic is 10.377 which is significant at 0.01 level, we reject the null hypothesis. Thus life satisfaction scores of the clergy differ with no of families in the parish. 


\section{Determinants of Life Satisfaction among the Clergy in Indian Orthodox Church: A Study in Central Travancore, Kerala State}

Life Satisfaction Score

\begin{tabular}{l|r|r|r|} 
Duncan $^{\mathrm{a}, \mathrm{b}}$ & \multirow{3}{|c|}{ Subset for alpha $=.05$} \\
\cline { 3 - 4 } No of families in Parish & $\mathrm{N}$ & \multicolumn{1}{|c|}{2} \\
\hline Above 500 & 13 & 147.9231 & \\
$100-500$ & 39 & & 166.3846 \\
Below 100 & 23 & & 175.4783 \\
Sig. & & 1.000 & .099 \\
\hline
\end{tabular}

Means for groups in homogeneous subsets are displayed.

a. Uses Harmonic Mean Sample Size $=20.542$.

b. The group sizes are unequal. The harmonic mean of the group sizes is used. Type I error levels are not guaranteed.

The life satisfaction scores of the two groups namely below 100 families and 100-500 families are not significantly different. The life satisfaction scores of other groups show significant difference when taken pair-wise.

\section{Life satisfaction and employment of spouse}

Testing whether life satisfaction and employment of spouse are associated. There is no relationship between life satisfaction and employment of spouse.

The tool used is the Chi-square test. The value of chi-square statistic is 0.054 which is not significant at 0.05 level. Hence we accept the null hypothesis. Thus life satisfaction and employment of spouse are not associated.

\section{Life Satisfaction and Theology Education}

Testing whether life satisfaction scores differ with theology education. Statistical tool used is one-way ANOVA.

\section{ANOVA}

Life Satisfaction Score

\begin{tabular}{|l|r|r|r|r|r|}
\hline & \multicolumn{1}{|c|}{$\begin{array}{c}\text { Sum of } \\
\text { Squares }\end{array}$} & df & Mean Square & \multicolumn{1}{c|}{ F } & Sig. \\
\hline Between Groups & 6532.551 & 2 & 3266.276 & 10.831 & .000 \\
Within Groups & 21713.396 & 72 & 301.575 & & \\
Total & 28245.947 & 74 & & & \\
\hline
\end{tabular}

The value of $\mathrm{F}$ statistic is 10.831 which are significant at 0.01 levels, we reject the null hypothesis. Thus life satisfaction scores of the clergy differ with theology education. The Duncan's test is used to find out which groups show significant difference when taken pair-wise. 


\section{Determinants of Life Satisfaction among the Clergy in Indian Orthodox Church: A Study in Central Travancore, Kerala State}

The life satisfaction scores of the groups namely undergraduates and graduates are not significantly different. The life satisfaction scores of post graduates stand on the top and there is significant difference between this group and other groups.

\section{ANALYSIS OF LIFE SATISFACTION IN THE CASE OF MARRIED CLERGY.}

The value of F statistic is 5.004 which is significant at 0.01 level, we reject the null hypothesis. Thus life satisfaction scores of the married clergy differ with duration of marital life.

The Duncan's test is used to find out which groups show significant difference when taken pairwise. The life satisfaction scores of the groups namely 5-10 years, 10-20 years and 20-35 years are not significantly different. Also the life satisfaction scores of the group namely up to 5 years is on the top and there is significant difference between this group and other groups.

\section{Life Satisfaction and Diocese.}

It says that there is no significant difference between the life satisfaction scores of clergy belonging to various dioceses. But the analysis mentions life satisfaction scores of the clergy differ with dioceses. The life satisfaction scores of clergy in Kottayam and Kollam are not significantly different; also the life satisfaction scores of clergy in Kollam and Thumpamon are not significantly different. However the life satisfaction scores of the clergy in Kottayam and Thumpamon are significantly different. It may be because of the difference in geographical area of the two diocese. So we reject the null Hypothesis.

\section{Life satisfaction scores and age}

The study says that the life satisfaction scores of the clergy differ with age.The life satisfaction scores of the clergy in the age group up to 30 years are significantly higher than that of other age groups and there is significant difference between this group and all other groups.So the hypothesis is not tenable.

\section{Life Satisfaction Scores and Income}

The study revealed that the income is significantly related to Life Satisfaction. It opines that there is no significant differences between the life satisfaction scores of clergy belonging to various income groups. We reject the null hypothesis. It may be because of the low level of income in the diocese even they are in higher level of their age. The life satisfaction scores of the clergy differ with income. The life satisfaction scores of the group having income below Rs 5000 and the group having income between Rs 5000-10000 are not significantly different, whereas the life satisfaction scores of other groups are significantly different when taken pair-wise. So the hypothesis is not tenable. 


\section{Determinants of Life Satisfaction among the Clergy in Indian Orthodox Church: A Study in Central Travancore, Kerala State}

\section{Life Satisfaction and general Education}

Null hypothesis says the life satisfaction scores of clergy do not differ with education. The study accepts the null hypothesis. Thus life satisfaction scores of the clergy do not differ with general education. Null Hypothesis is tenable.

\section{Life Satisfaction Scores and Marital Status}

By studying whether life satisfaction scores differ with marital status. The Null hypothesis 2 says Life satisfaction scores of married clergy and that of unmarried clergy are equal. Hence we accept the null hypothesis. That is there is no significant difference between the life satisfaction scores of clergy who are married and who are unmarried. So the hypothesis is tenable.

\section{Life Satisfaction Scores and Duration of Ministry}

The study reveals that the life satisfaction scores of the clergy differ with duration of ministry. The life satisfaction scores of the groups namely up to 5 years and 5-10 years are not significantly different, also the life satisfaction scores of the groups namely 10-20 years, 20-35 years and above 35 years are also not significantly different. It says at the beginning of the ministry clergy's life satisfaction diminishes. Also it is related to their health, activity etc. So we reject the null hypothesis. The hypothesis is not tenable.

\section{Life Satisfaction Scores and No. of families in the parish}

We had hypothesized that the life satisfaction scores of clergy do not differ with no of families in the parish .Our results revealed that the life satisfaction scores of the clergy differ with no of families in the parish. The life satisfaction scores of the two groups namely below 100 families and 100-500 families are not significantly different. The life satisfaction scores of other groups show significant difference when taken pair-wise. At my point the excess work in the parish, expectation, perfection, time management in the ministry are the main factors. The null hypothesis is not tenable.

\section{Life satisfaction and employment status of spouse}

The study proves that life satisfaction and employment status of spouse are not associated. Hence we accept the null hypothesis.

\section{Life Satisfaction and Theological Education}

The study opines that the life satisfaction scores of the clergy differ with theology education. We reject the null hypothesis which is, the life satisfaction scores of clergy do not differ with theological education. The life satisfaction scores of the groups namely undergraduates and graduates are not significantly different. The life satisfaction scores of post graduates stand on 


\section{Determinants of Life Satisfaction among the Clergy in Indian Orthodox Church: A Study in Central Travancore, Kerala State}

the top and there is significant difference between other groups. It may because of their awareness and spiritual outlook about the circumstances.

The hypothesis is not tenable.

\section{Life satisfaction and Duration of Married Life.}

The life satisfaction scores of the groups namely 5-10 years, 10-20 years and 20-35 years are not significantly different. Also the life satisfaction scores of the group namely up to 5 years is on the top and there is significant difference between this group and other groups. It is a common understanding that the life satisfaction may be significant in the beginning of their married life. Hence the null hypothesis is not tenable.

\section{IMPLICATIONS}

Often clergy men cannot open their problems to others because their self esteem is in high level. From the present experience of the ministry and the information from the study, it is essential that the clergy men have to get some mental support and counseling. For that the initiative work is to be done from the church itself. Diocese centered adjustment and work is to be done. In each diocese, trained priests must be appointed to help their fellow priests for their counseling. The awareness for the spouse of the married priests is an important matter. In the "Baskiyomo" (partner of priest) association meeting, classes must be conduct.

Unmarried priests should not left to live alone. Ashram should give opportunity to handle emotional problems of members in a healthy way. Adequate Financial support should be given to the clergy in order to overcome the financial problems. The Priest Welfare Fund should be function properly. Healthy relaxation techniques are essential to the clergy men; hearing to good music, preaching, yoga, breathing exercise, and meditation are also good.

The following means are suggested for stress management in the priestly ministry

1 Commitment to the Vocation

2 Sharing Problems through healthy interpersonal relationships.

3 Rest and recreation

4 Personal Prayer (Manalel, George, 2006,p.109).
A. Prayer gives the person a sense of security
B. It restores emotional equilibrium thus restoring calm and peace to the psyche
C. It solidifies and stabilizes ego- strength.
D. It enables the individual to transcend human conflicts and tragedies.

Clergy men are called for helping and understanding the difficulties of peoples. They have their own problems. Most often others will consider the clergy men as extra ordinary persons. The stress of the clergymen affects their life satisfaction and it results the ministry adversely. It is believed that the results of the present investigation may provide an awareness regarding the 


\section{Determinants of Life Satisfaction among the Clergy in Indian Orthodox Church: A Study in Central Travancore, Kerala State}

emotional level of Orthodox Clergy and need to improve the situation by adopting adequate measures.

\section{BIBLIOGRAPHY \& WEBLIOGRAPHY}

Albert, Pepitone,(1967), Self, Social Environment and Stress, New York: Appleton Century Crofts

Antony, John, (2003).Psychotherapies in Counseling, Dindigal: Anugraha Publications.

Boss, P.G.(1987).Family Stress, New York: Plenum,

Butler,Robert B \& Lewis,Myrna I (1973).Aging and Mental Health,St. Louis: C.V Mosby Campus.

D, Sinha,(1954).Psychological Study of Catastrophes,Patna University 6.

Dunbar, (1954) .Emotions and Bodily Changes, New York: Columbia University Press.

Erickson, Eric, (1959).Identity and the Life Cycle, New York: international University press.

Kemp, Charles F. (1985).The caring Pastor, Nashville: Abingdon Press.

Kothari, C.R, (2006). Research Methodology: Methods and Techniques, New Delhi: New age International Pub:

Lam, DJ \& Palsane, MN. (1997). Research on stress and coping. Contemporary Asian Approaches, New Delhi: Sage Publications.

Lam, palsane, (1997).Research on stress and coping. Contemporary Asian Approaches, New Delhi: Sage Publications.

Maslow, A.H, (1976). The father reaches of human nature, New York: Pengina Books Ltd, Jim Mc Martin, Personality psychology: A student centered approach (New Delhi: sage publication 1995.)

Mason, J.W, (1975), A Historical View of Stress Field, Journal of Human Stress.

Mathew, M. J.( 1993).Organization Theory and Behavior, Jaiur: RBS Pub,)

Meyer, Robert. C \& Newell, William T, (1969). Simulation in Business and Economics, Englewood Cliffs, NJ: Prentice Hall, inc.

Mosak, Harold H. (1919). Alderian psychotherapy in current psycho theories, edited by Raymond I cousins, Illinosis: F.E. Pealok publishers.

Pattil, G.D, Patil, M.D \& Kumar, D.S. (1991).The impact on life satisfaction of the elderly women In Quality of life Edited by I J Pradesh ,Varanasi: Association of Gerontology .

Pestonjee, D.M, (1999) .Stress and Coping: The Indian Experience, New Delhi: Sage Pub.

Selye, H.(1992) Stress in Health in Disease, Reading, MA: Butterworth 38.Sutherland and Cooper,

Sharf, Richards, (2004).Theories of Psychotherapy and counseling, California, Thomson brooks/ Cole,

ShultZ, Dunae P, EllenshuttZ \& Sidnay, (2000). Theories of personality, Belmont: wards worth.

Sousa, L., \& Lyubomirsky, S. (2001). Life satisfaction. In J. Worell (Ed.), Encylopedia of women and gender: Sex similarities and differences and the impact of society on gender, (Vol. 2, pp. 667-676). . San Diego, CA:

St. John of Kronstadt, (1994).Counsels on the Christian Priesthood, Crestwood, NY: St. Vladimir's Seminary Press. 


\section{JOURNALS}

A .Delongis, S. Folkman, \& Lazarus, R.S,(1988).The Impact of Daily Stress on Health and Mood: Psychological and Social Resources as Mediators Journal of Personality and Social Psychology.

Capsi A and Elder GH, "Life Satisfaction in old age: Social Psychology and History". Http://www.nlm.nih.gov/entrez/...

Daniel K Mroczek \& Arvin Spiro III, (2005) “Change in Life Satisfaction during Adult hood”. Journal of Personality and Social Psychology, 88/1

Diener, Suh, Lucas, \& Smith (1999) Buetell, N. (2006). "Life satisfaction, a Sloan Work and Family Encyclopedia entry”. Retrieved May 10, 2007, from the Sloan Work and Family Research Network

Fillit HM, Butter RN. O Connel AW, Albert MS, Birran JE, Cotman CW, et al. "Achieving and maintaining Cognitive Vaklidity with aging....../331/7509/141(5 January 2008,10.47 am)

Kenny Cribb, "Life Satisfaction and who has it(Abstract)" , http://www.google .co. in/ search ?q=life+ satisfaction \&hl=en \&lr=\&start=30\&sa=N,5November 2008

Morelli, G. , "Asceticism and Psychology in the Modern World" , Cited in http://www.orthodoxytoday.org/articles6/MorelliMonasticism.php.,13 Dec 2008,10.18 am

P K B Nair,: "The aged-their problems and need for social intervention : A study in Kerala" Paper prepared for the ministry of Social welfare, Government of India. New Delhi: Centre for social Research Trivandrum.

Pestonjee (1999) 'Stress Research, An applied Focus' in Journal Of Personality and Clinical Studies, and the book 'Stress and coping: The Indian Experience' ,New Delhi: Sage Publications

Shorter Oxford Dictionary, 1933

Stedman's Medical Dictionary (1982, 24 ${ }^{\text {th }}$ ed)

Vickers "The relationship of Defenses and Coping to Job Stress", (Unpublished Dissertation, University of Michigan, 1979) 